\title{
A Feminist Analysis of Caddy's Thoughts in The Sound and the Fury
}

\author{
LIU Xi, WANG Xiao-yan \\ Changchun University, Changchun, China
}

\begin{abstract}
William Faulkner was an outstanding writer who was awarded Nobel Prize for Literature and Pulitzer Prize for Fiction for his great contribution to American literature. In his whole literary life, he created many famous novels and short stories, such as, The Reivers, Absalom, Absalom, and A Rose for Emily. Published in 1929, The Sound and the Fury is Faulkner's masterpiece which employs several narrative styles, including stream of consciousness. The Sound and the Fury depicts two different typical women (a white woman and a black woman) who witness the development of feminism with the background of the fallen southern economy in America. The present paper aims to give a feminist analysis of Caddy's thoughts from the perspectives of her rebellion against the southern ladyhood and the pursuit of freedom and independence.
\end{abstract}

Keywords: female thoughts, pursuit, independence, freedom

\section{Introduction}

William Faulkner (1897-1962), one of the most effective and outstanding modern writers in American literature, is regarded as a unique writer who can express his thought on time spirit. In his golden time, his major classic novels reflect his southern complex. Faulkner expresses his adoration and yearning on southern natural sights and society, and betrays his sympathy and understanding for southern people and traditional customs.

In 1949, his masterpiece - The Sound and the Fury — was awarded the Nobel Prize for Literature. It is widely acknowledged as Faulkner's most outstanding and brilliant achievement, which shows his southern complex, and it is also the most brilliant achievement in modern American literature. The story is set in Jefferson, Mississippi, which focuses on the Compson family, former Southern aristocrats struggling to do with the degeneration and the collapse of their family and its reputation. Over the course of the 30 years or so related in the story, the family fell into the financial crisis, lost its religious loyalty and the respect of the town of Jefferson, and many of them died miserably. In this novel, Faulkner describes the history of downfall in an old family in Jefferson Town. That is also the history of the collapse and the vivid reflection of southern society, which implies the decline of Southern plantation economy and the rise of Northern capitalist economy. What really counts is the description of main characters, especially Caddy and Dilsey who display their feminism spirit in male-dominated society.

LIU Xi, lecturer, M.A., School of Foreign Languages, Changchun University.

WANG Xiao-yan, professor, M.A., School of Foreign Languages, Changchun University. 
The novel consists of four parts which relate many of the same episodes, each from a different perspective and thus with emphasis upon different themes and details. "The interweaving and nonlinear structure makes any true synopsis of the novel difficult, especially since the narrators are all unreliable in their own way, making their accounts not necessarily trustworthy at all times" (Deland, 1990, p. 321). Furthermore, in order to create a literary aesthetics and attraction, Faulkner uses italics to show writing features in each part where the narrative is moving into an important moment belonging to the past. The present paper aims to analyze the feminist thoughts of Caddy from the perspectives of her rebellion against the southern ladyhood and her pursuit for independence and freedom

\section{Feminist Thoughts and Patriarchal Society}

In The Sound and the Fury, the author reveals how women grasp their own fate for dignity and freedom, and gradually go into depravity in man-dominated society, which reflects the spirit of feminism. Patriarchy is a social system in which men hold dominating power. Males predominate in different social and domestic roles, such as, political leadership, social privilege, moral authority, and control of wealth. Within the family, males or male-figures hold authoritative power over females and children.

Many patriarchal societies are also patrilineal, meaning that property and title are inherited by the male lineage. The female equivalent is matriarchy. Historically, patriarchy has manifested itself in the social, legal, political, and economic organization of a range of different cultures. (Fedwa, 2007, p. 29)

In the patriarchy society, females in western countries have been subjected to the oppression and exploitation by males for almost over a thousand years. Since the first wave of women liberation movement, females began to establish a consciousness to rebel against men in order to deprive themselves of the oppressed and the exploited. In this sense, many literary works center on the theme of feminism so as to help more females awakening spiritually. In The Sound and the Fury, the heroin Caddy sets a good example for women who expect to have a sober mind and pioneering spirit against inequality between men and women.

The word "feminism" comes from France in the 18th century, which refers to women liberation, that is, "women's pursuit for gender equality with men which provides them with legal rights to express their own voices to strive for a comparatively higher social status" (Castille, 1992, p. 430). Women's liberation movement became prevailing in Britain and America in the 1960s and 1970s which introduced pioneering spirit upon women and even writers in that era. Generally speaking, feminism can be simply divided into three categories according to the different backgrounds of women. In the process of movement, white feminism promoted black feminism, in turn, black feminism enriched white feminism. At first, colored feminists (the third world feminists) offered a telling criticism to the main stream feminism (white feminism). They admitted sexual identity, and specially emphasized the relations between different races and classes. It is of great necessity to point out that a woman should belong to a certain class and come from certain nation, so each woman has her own unique experiences. Bell Hooks, a famous black feminist, insists that "white women's feminism theories can not summarize the diversity and complexity of all kinds of women's, and white women can not represent the benefits of women from different races either" (Hooks, 1984, p. 58). From now on, black feminism is advanced and diversified further. The acts of black feminist carried special significance, which took unique viewpoints to display specific value outlook on culture, race, class, social sex, politics, and economy, even individual factors. The concept of the black feminism that opposes hegemony and fights for right and justice enlightens people who have the same 
dream to pursue.

\section{Caddy's Rebellion Against the Southern Ladyhood}

In The Sound and the Fury, there is no denying to say that Caddy is a complicated protagonist who is both loved and hated by men. Her character and dispositions are brought into being mainly by social factors at her time. As old saying goes: Where there is oppression, there is resistance. The whole social environment suppresses the nature of human, however, there still exist the solutions to it though it is a long way to go.

At that time, southern economy in America largely depended on southern plantation economy. Such economic system determined the value of southern man-dominated society. In this society, it focused on race, sex, class, and a series of stern rules in all respects. In the family existing in such a society, men were in an absolutely dominated position, that is, a father was the center of a family. As a father, a male was expected to be majestic and heroic so as to occupy the highest power; he should be a role of determiner and leader of domestic affairs. As a mother, a woman should be a pure, gracious, and noble lady. Moreover, she should be busy with family matters and take good care of all the members, in the meanwhile, her husband was expected to be the whole world for her. This was the reflection of the common value in southern society, and anyone who failed to follow the trend would be satirized and denounced. Faulkner once put it: "In South, above all, there is still a common acceptance of the world, a common view of life, and a common morality'(Faulkner, 2004, p. 31).

The end of American Civil War was a declaration of the abolishment of slavery. However, the image of the southern ladyhood was still deep-rooted in the fallen environment of southern plantation economy and traditional value, because southern people could intend to protect last valuable spiritual support from being collapsed so that women maintained the image of the ladyhood. The image of Caddy was created under such social circumstances. Where there is a specific environment, there is a hero to be different. As a woman, there was a period of time for her to grow up from an adolescent to an adult. Caddy was endowed with natural qualities, such as, kind-hearted, passionate, and courageous enough to love and hate, to think, and to behave. She was a special girl who was powerful enough to internalize the independent and pioneering spirit; she still remained a bit bewildered though she was like other women oppressed in the same patriarchal pattern.

Caddy always tended to rival for priority since childhood. No matter what happened or what would happen, she would always make every effort to take the first place in any competition. While playing the games with boys, she was active to be the king or the general. And when her grandmother passed away, only Caddy dared to clamber up the tree to discover the secret of her house and tell what happened to her brothers, however, her brother were too timid to follow her example.

In a man-dominated society, men held that mediocrity was the virtue of women so that many traditional women became the victims. Caddy's mother, Mrs. Compson, was a good example because she held that women were born to take care of men and to teach children, so women should maintain traditional images. Nevertheless, fortunately and amazingly, Caddy never followed in her mother's steps and she took men as her example and almost acquired the rights as a man had. She went to school like boys at the age of seven which seemed to be unbelievable as for a girl. Caddy started to date different kinds of men when she became an adult, which was the public rebellion to her family. Just as what she said: "I will run away and never come back" (Faulkner, 1993, p. 18). That was her declaration to fight against imprisoned social system in patriarchal society. 
What she did could not be understood by her family and society, but nobody could deny that it was the strong rebellion to the patriarchal tradition for she ran in the opposite position to the image of ladyhood. As a result, she touched the baseline of the society. Virtue stood for family's fame and deep-rooted traditional value, so in man-dominated society, a woman's body belonged to a man and family, which could be his inviolability property. As Faulkner once put it: "The value of women only lies in virtue, and it is more important than life. To keep their virtue, men prevent their physical desire and deprive of right of voice" (Faulkner, 2004, p.194). If a woman failed to maintain an image of ladyhood, she could be regarded as the atrocious demon for the society was flooded with gender prejudices and discrimination.

Although Caddy was harshly denounced finally, she still survived in the man-dominated society. After surviving the collapse of family and disillusion of dream, she became a symbol of liberation, freedom, and hope for women eventually.

\section{Caddy's Pursuit of Freedom and Independence}

In the whole story, her frequent absence and silence arouse more curiosity of the readers since she was not given enough chances to voice, which was the reflection of women's social status at that time. With such skills of plot knitting, Faulkner never disregards or disrespects women at all, instead, he respects and admires women. What he intends to express is his love and sympathy for women like Caddy through the perspective of three brothers. The narrative of males can be more objective to show the hardships and dilemma of females at that time.

Benjy was Caddy's youngest brother with intelligence as a three-year-old child. Since he was a kid , Benjy desired for maternal love, however, Mrs. Compson was a bit indifferent to him. Caddy was his only sister who could devote her love and gentleness to protecting him. Benjy viewed Caddy as his mother and a pure angel. When Caddy began to wear adult clothes and use perfume to date men, which was different from what she used to be; Benjy could not bear it first, because his little sister was like an angel, pure and simple, so that she could not be desecrated by other men. Benjy was scared to confront the growth and independence of Caddy. It seemed to him that his sister began to lose her virtues as a pure traditional girl. He was too immature to learn that Caddy came to show her understanding towards independence and freedom.

Quentin was Caddy's eldest brother who had strong affections for her. In the novel, he acted as a spokesman of the man-dominated society. He regarded Caddy's chastity as family honor and fame. He was so infatuated with her chastity that in order to protect her, he tried to prohibit Caddy from pursuing love. After Caddy lost her chastity, he expelled the man who claimed to be responsible for her. He cherished Caddy's virtue, once it was destroyed, he became crazy and helpless. He hated Caddy and viewed her as an adulteress. "He must value about all not her but the virginity of which she was custodian and on which she placed no value whatever" (Faulkner, 1993, p. 412). A woman's chastity was valuable in a noble family, especially for family Compson so that in this sense, Caddy was absolutely a deviationist based on such patriarchal value system.

Caddy's young brother, Jason, held a complicated feeling to her, both contempt and resentment. Jason was not only another spokesman of man-dominated society, but also a product of capitalist economy. For one thing, he despised and loathed women and viewed their chastity as the honor and reputation of the family. For another, with the development of capitalist economy, he became a follower of money worship and believed that money meat everything to him. He would rather betray his sister for money, just as he betrayed his sister' marriage for 
his job. However, when Caddy's husband discarded her, Jason lost his job as well so that Caddy meant nothing just like deserted rubbish in the eyes of Jason. Later, he harbored indecent thoughts about Caddy's daughter in order to revenge her. Caddy was not allowed to see her daughter unless she give him money. Finally, Caddy's daughter stole Jason's money, which indicated a threat o man's authority.

In the previous episodes, Caddy seemed to play a less important role, compared with her three brothers. Nevertheless, in fact, all the three brothers acted as the spokesman of patriarchal society because they all showed the desire to control their sister, Caddy, rather than protecting her. In the process to fight against the spiritual shackles brought by the brothers, Caddy displayed her great courage to be independent and free by chasing after her love and even lost her chastity. Though involved in the whirlpool of man-dominated society, Caddy made good use of her awakening feminist consciousness to rebel against inequality and fight for independence and freedom.

\section{Conclusion}

The Sound and the Fury was created in the 1920s when women were thrown into the situation with the absence of discourse right. Southern America in that era was a typical patriarchal society where women were oppressed and exploited by man's power. This novel not only depicts special female images, but also reveals males' attitudes and viewpoints towards females so as to make us discover men's inner world. It seems that women at that time became the victims of man-dominated society. Under such circumstances, the existence of female protagonist of the story, Caddy, can be well considered as a proof to show that a minority of women came to establish the feminist consciousness with pioneering spirit.

On one hand, we may think that Caddy was unfortunate because she was born into that patriarchal family and into that man-dominated society; while, on the other hand, we may argue that just because she suffered a lot in such a family and social pattern, she began to establish feminist consciousness and even survive and struggle in the man-dominated world. What she had done and said was an absolute courage to the women at her time. In modern time, feminism develops so rapidly so that females are gradually respected and equally treated by men. Their social position has changed radically. Such is the great achievement that a writer like Faulkner and his followers can achieve.

\section{References}

Castille, P. D. (1992). Dilsey's Easter conversion in Faulkner's The Sound and the Fury. Studies in the Novel, 24, 423-33.

Deland, A. (1990). Through days of Easter: Time and narrative in The Sound and the Fury. Literature and Theology, 4(3), 311-24. Faulkner, W. (1993). The sound and the fury. New York: W. W. Norton \& Company.

Faulkner, W. (2004). Essays, speeches and public letters. New York: The New American Library.

Fedwa, M. D. (2007). Encyclopedia of sex and gender. Detroit: Macmillan Publishing Co..

Hooks, B. (1984). Cultural criticism and transformation. Boston: South End Press.

Margaret, F. (1999). Women in the nineteenth century. Beijing: Foreign Language Teaching and Research Press.

Ross, S. M. (1996). Reading Faulkner: "The Sound and the Fury”. Jackson: UP of Mississippi.

Tredell, N. (2009). William Faulkner: The Sound and the Fury and As I Lay Dying (1st ed.). New York: Columbia University Press. 